\title{
KNOWLEDGE AND INNOVATION PARTNERSHIPS FOR SMART AND SUSTAINABLE TERRITORIAL DEVELOPMENT
}

\author{
Sandra ŠŪMANE, Baltic Studies Centre, Kokneses prospekts 26-2, Riga LV-1014, Latvia, sandra.sumane@gmail.com \\ (corresponding author) \\ Anda ÄDAMSONE-FISKOVIČA, Baltic Studies Centre, Kokneses prospekts 26-2, Riga LV-1014, Latvia, andaaf@ gmail.com \\ Linda CĪRULE, Baltic Studies Centre, Kokneses prospekts 26-2, Riga LV-1014, Latvia, mrslindacirule@gmail.com \\ Miḳelis GRĪVIN̦Š, Baltic Studies Centre, Kokneses prospekts 26-2, Riga LV-1014, Latvia, mikelis.grivins@gmail.com \\ Emīls KīLLIS, Baltic Studies Centre, Kokneses prospekts 26-2, Riga LV-1014, Latvia, emils.kilis@gmail.com \\ Marija Stefānija SKUDRA, Baltic Studies Centre, Kokneses prospekts 26-2, Riga LV-1014, Latvia, skudramarija@gmail.com \\ Tālis TISENKOPFS, Baltic Studies Centre, Kokneses prospekts 26-2, Riga LV-1014, Latvia, talis.tisenkopfs@lu.lv
}

\begin{abstract}
The complexity of contemporary territorial development challenges - such as uneven growth trajectories triggered by monocentric development, social and economic inequalities, depopulation of rural and remote territories, environmental degradation - calls for addressing them in a systemic, multi-level and cross-sectoral manner. Collaborative and participatory approaches are increasingly recognised as a precondition for smart and sustainable territorial development where local resources and digital technologies are employed in ways that stimulate economic growth, increase social integration and wellbeing, and improve environmental conditions. We apply the framework of quadruple helix to explore the role of knowledge and innovation partnerships (KIPs) in three key areas of contemporary territorial development in Latvia, i.e., regional food systems, rural-urban interfaces, and rural digitalisation. The study is based on a review and synthesis of theme-specific results from across 11 national and European projects carried out by the Baltic Studies Centre since 2007, and national expert interviews. The results suggest that KIPs in rural and territorial development contexts have specific constellations and activities both within and across the three areas. It can be more challenging to establish KIPs there than in urban surroundings because of scarcer resources. When established, KIPs allow for pooling resources of different stakeholders for joint practical problem solving. Improved understanding and knowledge of local resources and systems within which those resources circulate, and targeted support for multi-actor knowledge and innovation collaboration within and across territories, including rural-urban ones, are needed to enable KIPs for sustainable territorial development.
\end{abstract}

Keywords: quadruple helix, sustainable territorial development, rural-urban linkages, food systems, digitalisation.

\section{INTRODUCTION}

The complexity of contemporary territorial development challenges - such as uneven growth trajectories triggered by monocentric development, social and economic inequalities, depopulation of rural and remote territories, environmental degradation - calls for addressing them in a systemic, multi-level and cross-sectoral manner. Such an approach also implies involvement and cooperation of relevant stakeholder groups, including research, industry, government and civil society. Collaborative and participatory approaches are increasingly recognised as a precondition for smart and sustainable development, i.e. development where local resources and digital technologies are employed in new ways that stimulate economic growth, increase social integration and wellbeing, and improve environmental conditions (Koopmans et al., 2018; Nordberg et al., 2020). However, operation of multi-actor collaborations in territorial, particularly in rural, contexts so far has been less explored. The goal of the paper is to advance knowledge about the role of multi-actor collaboration in smart and sustainable territorial development. The analysis is guided by the following research questions: how broader development trends shape such territorial collaboration, which actors participate in the development of new solutions, how they do it and with what outcomes.

We conceptualise multi-actor collaboration as knowledge and innovation partnerships (KIPs) as they bring together various stakeholders and aim to align their interests and integrate their resources, in particular knowledge, for a shared goal in new joint territorial development initiatives. For in-depth exploration of KIPs in the context of smart and sustainable territorial development in Latvia, we have selected three interconnected fields of contemporary territorial development: rural-urban linkages, regional food systems, and rural digitalisation. These fields are among the key ones for smart and sustainable territorial development in Latvia, and they are also addressed in the National Development Plan 2021-2027 as essential for reaching national development priorities (Latvia National... 2021-2027). They have also appeared central during the Covid-19 pandemic in view of social and economic adaptation and recovery. Existing food

Copyright (C) 2021 The Authors. Published by Vytautas Magnus University. This is an open-access article distributed under the terms of the Creative Commons Attribution License (CC BY 4.0), which permits unrestricted use, distribution, and reproduction in any medium, provided the original author and source are credited. 
systems experienced shocks due to interruptions in the provision of inputs, labour and outlets in supply chains, and calls for the localisation and greening of food systems have been made (Bakalis et al., 2020; Rowan, Galanakis, 2020). The physical distancing during the pandemic has underlined the importance of digital tools and skills for social and economic life, and their development and dissemination across different territories and social groups are considered an imminent part of future development strategies (Dwivedi et al., 2020). Finally, rural and urban places have experienced the lockdown during the pandemic differently, with advantages and disadvantages on both sides. Place-sensitive and inclusive solutions, strengthening of rural-urban linkages at regional level for win-win solutions and synergies are crucial for resilient, integrated territorial development (Malatzky et al., 2020).

\section{METHODS: THEORETICAL AND METHODOLOGICAL APPROACH}

We base our study upon interactive innovation approach (Pigford et al., 2018; Klerkx et al., 2012) that is supplanting the linear approach to innovation and knowledge transfer, and highlights stakeholders' collaboration in innovation development. According to this chosen perspective, innovation is co-produced through multi-actor networking, mutual learning and knowledge exchange. Such an interactive innovation process involves a diversity of innovation actors, knowledge sources, and learning modes, and their combination allows for effectively tackling complex development problems. To support connections, mutual learning and the coordination of stakeholders in interactive innovation networks, public policy support measures have been introduced, notably the multi-actor approach and thematic networks promoted by the European Commission (van Oost, 2017).

Specifically, we apply the quadruple helix framework that considers territorial development as an interactive knowledge and innovation process with the involvement of four key stakeholder groups, i.e. government, industry, academia, and civil society. This multi-actor collaboration is aimed at knowledge sharing, integration, and application for innovative solutions. In comparison to the triple helix approach to innovation that considers research-industry-government collaboration focused on technology-based economic growth, the quadruple helix approach adds on and stresses the role of civil society, societal demand, and social innovations in territorial development trajectories (Carayannis, Campbell, 2009). Quadruple helix partnerships strive to be more responsive to the tripartite goal of smart, sustainable and inclusive growth (Carayannis, Campbell, 2014), with an emphasis on public engagement and community service (AdamsoneFiskovica et al., 2009) and an underlying ethos of responsible research and innovation (Owen et al., 2012).

While academic knowledge on the quadruple helix has been growing, its operationalisation and practical implementation at a territorial level have received less attention (Cavallini et al., 2016). In this paper we address this gap by investigating knowledge and innovation partnerships in regions, and specifically in rural contexts where the quadruple helix framework has been less employed. More efforts are needed to induce quadruple helix collaboration for innovative development in rural contexts (Kolehmainen et al., 2016). Studies show that civil society has a particular role to play in innovative development of rural regions as other helices can be absent or with limited capacities to actively engage and facilitate innovation (Kolehmainen et al., 2016; Makkonen, Kahila, 2021). Effective networking platforms, co-creation of joint regional development vision, transparency of responsibilities of each stakeholder, leadership and facilitation or knowledge brokerage between different stakeholder groups, involvement of end-users are pointed among key success factors of effective KIPs in rural contexts (Kolehmainen et al., 2016; Cronin et al., 2021).

To explore developments and the role of KIPs in the three thematic fields of rural-urban linkages, regional food systems, and rural digitalisation, we use a mixed-method approach: a review and synthesis of theme-specific results from across 11 national and European projects carried out by the Baltic Studies Centre since 2007 (AgriLink, DESIRA, ETUDE, FoodLinks, PLAID, ROBUST, SALSA, SINFO, SOLINSA, SUPURBFOOD, TRUSt ${ }^{1}$ ), and national expert interviews.

The project materials (reports, publications, data) were reviewed with the goal of identifying sustainable solutions in practice that are developed in multi-actor collaboration in the three thematic fields. Solutions were understood as purposeful strategies that actors develop and implement with resources at hand in reaction to specific hampering or driving conditions that highlight some sustainability challenge. In total, 35 solutions were identified for further analysis. We adopted the conceptual model of "conditions-strategy-performance" (Grando et al., 2019) to analyse the selected solutions. The model implies that solutions are triggered by a combination of different external and internal conditions which urge agents to collaborate for their shared purposes. Each solution was analysed regarding the sustainability challenges it addresses, the constellation of agents and their roles and resources used, and sustainability outcomes.

Expert interviews were used to verify the identified solutions and gain in-depth insights about the multi-actor collaboration in KIPs. Seven experts representing the three thematic fields and four helices were interviewed. The interviews were audio-recorded and analysed according to the predefined themes: (1) particularity of KIPs in local, rural and territorial contexts, (2) innovative solutions introduced by KIPs, and (3) specific roles of each stakeholder group in KIPs.

\footnotetext{
${ }^{1}$ AgriLink :Agricultural knowledge: linking farmers, advisors and researchers to boost innovation (2017-2021); DESIRA: Digitisation: Economic and social impacts in rural areas (2019-2023); ETUDE: Enlarging the theoretical understanding of rural development (2007-2009); FoodLinks: Knowledge brokerage to promote sustainable food production and consumption: Linking scientists, policy makers and civil society organisations (2011-2013); PLAID: Peer-to-peer Learning: Accessing Innovation through Demonstration (2017-2019); ROBUST: Rural-urban outlooks: Unlocking synergies (2017-2021); SALSA: Small farms, small food businesses and sustainable food security (2016-2020); SINFO: Social Innovation in Food Provision: Pathways to Sustainable Production and Consumption (2018-2021); SOLINSA: Agricultural knowledge systems in transition: support of learning and innovation networks for sustainable agriculture; SUPURBFOOD: Towards sustainable modes of urban and peri-urban food provisioning (2012-2015); TRUSt: Innovations in Non-timber Forest Products: Towards Rural development and Sustainability (2017-2020).
} 


\section{RESULTS: KNOWLEDGE AND INNOVATION PARTNERSHIPS IN ACTION}

One of the key challenges that smart and sustainable territorial development addresses is how to ensure development in terms of wellbeing, economic growth and sound environment throughout a country or a region, regardless of the geographical location, socio-demographic, economic and environmental profiles of each place, while taking into account their specificities. When considering territorial development, rural and urban areas are often approached in development planning and implementation as separate spaces with different needs and development potential. Cities have traditionally been seen as development centres due to many different resources they concentrate that stimulate more dynamics and innovation. In turn, rural areas are rather considered as areas to be developed, characterised by the presence of nature. economic activities based on the use of natural resources (agriculture and food production, forestry), more dispersed population and social activities. They also have different development policy and governance instruments, whose ability to align the different development rates and levels of prosperity appear to be limited though. In Latvia, for example, over a 10-year period, the population has decreased more rapidly in rural areas than in urban ones (CSP, 2021); the average income per household member in rural areas remains lower than in cities, although they are slightly more increasing in rural areas, and the income gap is reducing (CSP, 2019).

To implement an even sustainable territorial development, the acknowledgement and enhancement of rural-urban linkages become prominent. Such an integrated approach to territorial development planning where rural and urban territories are considered in conjunction is also increasingly driven by territorial policy and development instruments, such as the EU Territorial Cohesion Policy, the EU Territorial Development Programme 2020, the guidelines of the United Nations Habitat programme for urban policy, spatial planning and rural-urban links, etc. Historically, rural-urban linkages have been evolving as different interactions between rural and urban areas consisting of flows of humans, products, capital and information, and including a range of sectors and activities, such as agriculture, services and production (UN-Habitat, 2020). Each of the territories has its specific development resources and their connection in sustainable ways can generate mutually beneficial synergies and solve shared challenges, like, provision of services, management of natural resources, demographics, etc. Enhanced rural and urban linkages are possible through new governance and business models and social movements aimed at sustainable management and exploitation of local resources. We have examined four domains that illustrate rural-urban linkages and their potential in enhancing sustainable territorial development: integrated regional policies, networks for development cooperation, food linkages, and digitalisation.

Integrated regional development policy means that the planning and implementation of territorial and sectoral policies regards rural and urban development in conjunction, and that it integrates the needs, challenges and opportunities of both rural and urban areas. Such an approach to development planning and implementation may require reviewing of traditionally segregated policies and to extend or link them (for instance, by moving from agricultural policy that focuses on food production in rural areas to food policies that link food production to broader food systems beyond rural areas). Moreover, an integrated approach involves a more open policy process, including representatives of local governments and societal groups both from rural areas and cities and from several administrative units. Such an approach would allow for better integration of rural needs - that, according to aexpert's opinion, remain neglected - in territorial development policies. An integrated regional policy can take the form of joint development documents, the creation of new regional governance structures, such as rural-urban partnerships. The outcome of integrated regional development is an improved well-being of rural and urban inhabitants, and social and economic development as well as enhanced environmental situation of the whole region rather than selected areas.

The Tukums region's cultural strategy provides an example of an integrated approach to regional development. The Tukums municipality has a vast network of cultural institutions and traditions that ensure an active cultural life in the town and parishes. However, the municipality faced a challenge to improve the coordination, quality and accessibility of the cultural life with its limited resources. In 2018, inspired by the EU project ROBUST, the Tukums municipality in cooperation with the research institute Baltic Studies Centre launched the process of developing a joint cultural strategy for the Tukums region. The process actively involved a wide range of cultural institutions and stakeholders administrators, workers and users from the whole municipality. The process resulted in a development document - a joint regional cultural strategy, which was approved by the Tukums region council in 2020. The shared vision for the development of the cultural sector in the Tukums municipality is binding to all cultural stakeholders - municipalities, private and non-governmental sectors, and their cooperation is a precondition of its successful implementation.

Networks for development cooperation embody the principle of implementing territorial development with active involvement of and cooperation between rural and urban entrepreneurs, NGOs, citizens, authorities. Networks for development cooperation allow the pooling of resources belonging to individual organisations, social groups or individuals for the achievement of mutually beneficial and common objectives in the region. As such they are also enhancing innovation since this kind of networks enable solutions that individual partners may not be able to find, develop and implement because of their limited resources. Development cooperation also has greater potential to encourage wider and socially sustainable changes as it involves different groups of society, ensuring that their interests are represented and needs addressed. Several experts pointed to the central role of mediators or facilitators in the establishment and redeployment of development cooperation network as they bring - otherwise disconnected - partners together and facilitates their communication and cooperation. Local authorities can play a central role in launching development cooperation by establishing participation and cooperation platforms, introducing support instruments or investing their resources in cooperation initiatives. Development cooperation addresses practical needs of inhabitants and entrepreneurs, and can intervene in solving a range of territorial development issues. 
The Straupe rural goods market is an outcome of cooperation development. The market is designed as a place where local producers and consumers meet with an aim to promote local and environmentally friendly food. The development of the market involved a broad network of stakeholders from the locality and beyond. Initially local activists mobilised likeminded people, including farmers, in the rural community of Straupe, around the market idea. The local and regional government's strategic and financial support for the market was essential. The local dairy provided its land for the organisation of the market. The local tourism association supported marketing activities. As the Straupe market was among the first farmer markets in Latvia, the information and advice regarding the binding regulations provided by the state controlling institutions - the Food and Veterinary Service and the State Revenue Service - were helpful. In order to change the constraining national regulatory framework for the organisation of farmer markets, the market organisers cooperated with farmer lobby organisations. To strengthen the market's identity, it joined the international Slow food movement. Finally, the market succeeded to attract many devoted buyers from the neighbourhood and beyond who are interested in authentic local products and in supporting local producers. The local market has improved market access and economic situation of individual small and artisanal producers, and it also has boosted the local economy, both the food sector and tourism as the market has become an object of attraction for tourists. Regarding social development, direct interactions with customers contribute to the valorisation and recognition of farmers' work and local products. The market brings together local community, serves as an interface between rural and urban inhabitants, and contributes to local social life.

The market also illustrates that re-established food links between rural and urban areas can enhance sustainable regional food systems with positive impacts on broader territorial development. Food has traditionally linked rural producers and urban consumers, but in many places these links have disappeared or weakened at local level along with industrialisation of food production and distribution that has introduced many middlemen in the food chain. In addition, the agro-industrial model of food production and distribution has had a range of other social, economic and environmental impacts on territorial development, such as rural depopulation, loss of biodiversity, weak farmers' position in the food chain, limited food sovereignty, etc. Recent food-related policies, strategies and support measures, including the EU Farm to fork strategy and the Green deal, aspire to promote systemic transition of food systems towards sustainability. An increasing public awareness of the social, environmental and economic impacts of food production, distribution and consumption leads to growing demand for local food and development of local food chains that strengthen regional food systems. There are many types of local food promotion and distribution arrangements that are implemented by different public and private food stakeholders: direct sales on farms, online sales platforms, farmer markets, direct purchase groups, local food procurement, local food branding, commercialisation of culinary heritage, etc. They all have a good potential to improve farmers' social and economic situation, increase transparency and solidarity between producers and consumers. They can bring about environmental benefits through reducing food miles, promoting more environmentally friendly food production, and have a positive impact on regional social and economic development through activated new market interactions and cooperation. Through localised or shortened food chains the regional control of food governance can be increased.

For instance, direct food purchase groups in Latvia have been developed in response to a growing criticism of industrialised food, and in search for healthy, ethically, and environmentally sounder food. These groups are collective initiatives launched by consumers in cooperation with local producers. They provide an opportunity for urban consumers to buy food directly from local farmers that otherwise is accessible to a limited extent at the usual food purchase sites. As part of the direct purchase movement, farm visits are organised during which group members can gain knowledge of food production. The groups not only give urban consumers access to local, seasonal, also healthy, and organic food without middlemen and at a lower price, but also strengthen urban consumer communities through their members' voluntary cooperation and shared solidarity with local producers.

Many initiatives that contain the idea of food system reorganisation remain local though. To facilitate their scaling out and systemic transition towards sustainability in food supply chains, enhanced collective and public support measures can be indispensable. A shared view of the desirable sustainable transition within a larger group of food chain actors can reduce institutional constraints to change and lead to the introduction of new support instruments. Food governance institutions already possess tools that can be effectively used to stimulate sustainable transitions in food systems. Several experts pointed that more public efforts are needed to support local food and redirect local food production towards smart and sustainable practices. One of the most prominent tools is public food procurement that provides effective means to public institutions involved in food governance and organisation of food procurement to shape food production, distribution and consumption practices. Green public procurement and dynamic public procurement are two examples how to support reaching environmental goals and participation of local suppliers in food procurement calls.

Finally, rural digitalisation has a good potential to open up new development opportunities, reduce territorial development disparities, reconnect and strengthen links between rural and urban areas. Digitalisation involves both technological and social components. It refers to transition to digital tools and technologies in different sectors, while also promoting changes in people's day-to-day communication, culture and economy. Technological development certainly contributes to digitalisation, but the skills and ideas needed to use digital technologies and the solutions they offer also matter. The National Development Plan of Latvia for 2021-2027 states that digitalisation will have an impact in all sectors. However, there are concerns that the major positive effects of digitalisation might concentrate in urban areas where digital infrastructure and skills are better developed. Therefore, digitalisation could create even greater social and regional disparities and deepen the current gaps and inequalities between cities and rural areas.

In response to these concerns, the issue of rural digitalisation becomes prominent, in particular, with regards to improvement of rural digital infrastructure and digital skills of rural populations in order to make better use of the opportunities created by digital transformation. Digitalisation is at the heart of the EU concept of Smart Villages to 
enhance traditional and new networks and services for the benefit of inhabitants, businesses and governments. Digitalisation can act as a counterweight to "chronic" negative trends in rural development. It creates new opportunities for more efficient and economic provision of different services for rural and less populated areas, while strengthening citizens' skills to exploit the opportunities created by digital technologies. Several experts stressed the potential of digital tools in pooling resources and facilitating collaboration for collective benefits. Digitalisation and the spread of Internet and information technologies in rural areas open up a variety of opportunities for new employment (e.g. remote work), business (e.g. digital services, online commerce) and also life-styles (connecting remote urban work with rural life or vice versa).

For instance, in agriculture, the fragmented offer of advisory services for fruit growers in Latvia can be overcome by an online advice platform for farmers. Agricultural advice on fruit growing is provided by different organisations and individuals throughout Latvia, and producers often have incomplete information where to look for professional advice. In response to this, a digital advice platform is developed within the EU AgriLink project in cooperation between researchers, fruit growers, their association and IT developers. The platform will provide fruit growers with a full picture of the available advisors and improve their access to advice and various knowledge sources. To make the digital tool user-friendly, farmers are involved in its development, and they inform on their knowledge needs and the sources of advice they use. The Latvian Association of Fruit Growers will ensure the maintenance and renewal of the advice platform in long-term.

\section{CONCLUSIONS}

Implementation of smart and sustainable territorial development is closely linked to global changes, international strategies, as well as the local context, and expectations, opportunities and visions of local stakeholder groups. While there are many drivers of innovative solutions in a broader social, economic and environmental context, sustainable solutions require that they are well adapted to local situations and needs. This means active participation of local stakeholders in designing and implementing novel solutions.

Different stakeholders can initiate innovative solutions in territorial development contexts, but their implementation often require collaboration between different stakeholder groups. Particularly in rural context, KIPs consist of specific stakeholder constellations, and less typical innovation actors such as municipalities, other public institutions, local residents, small farmers etc. appear as innovation co-authors. KIPs allow for joining resources of different stakeholders for joint practical problem solving. Their innovation activities in territorial development contexts can be less radical, but are often practical, user-oriented, and address local needs. However, it can be more challenging to establish KIPs in rural areas because of scarcer resources available there.

Rural areas have specific resources - food, local culture, knowledge, natural resources, lifestyles, etc. - that can be effectively used for smart and sustainable territorial development. Improved understanding and knowledge of local resources and of systems within which those resources circulate, including rural-urban interface, are needed to enable KIPs for sustainable territorial development.

Strengthening the participatory approach in regional governance and the implementation of development activities by actively involving rural and urban populations, entrepreneurs, governments, and researchers, and facilitating their cooperation can contribute to the development of more effective solutions. Targeted support for multi-actor knowledge and innovation collaboration within and across territories, and beyond administrative units can serve that purpose. When promoting multi-actor networking platforms and implementing collaborative solutions, special attention should be paid to the involvement of mentors and knowledge brokers to facilitate interactions and collaboration between different stakeholders.

While technical infrastructure, technological development and funding are needed for reaching smart and sustainable territorial development goals, it has also a strong social dimension. Such a development is very much linked to the territorial human and social capital, the ability of local stakeholders to see and add value to local resources, to collaborate mutually and build connections to development trends in a broader context.

Acknowledgement. This work was carried out under the EKIP (Enacting user-centred knowledge and innovation partnerships for smart and sustainable territorial development) project, funded by the Latvian Council of Science, Fundamental and applied research project programme, grant agreement nr. lzp-2020/2-0133.

\section{REFERENCES}

1. Adamsone-Fiskovica, A., Kristapsons, J., Tjunina, E., Ulnicane-Ozolina, I. 2009. Moving beyond teaching and research: economic and social tasks of universities in Latvia. Science and Public Policy, Vol. 36(2), pp. 133-137. https://doi.org/10.3152/030234209X406836

2. Bakalis, S., Valdramidis, V. P., Argyropoulos, D., Ahrne, L., Chen, J., Cullen, P. J., Cummins, E., Datta, A. K., Emmanouilidis, C., Foster, T., Fryer, P. J., Gouseti, O., Hospido, A., Knoerzer, K., Le Bail, A., Marangoni, A. G., Rao, P., Schlüter, O. K., Taoukis, P., Xanthakis, E., van Impe, J. F. M. 2020. Perspectives from CO+RE: How COVID-19 changed our food systems and food security paradigms. Current Research in Food Science, Vol. 3, pp. 166-172. https://doi.org/10.1016/j.crfs.2020.05.003

3. Canali, S., Antichi, D., Cristiano, S., Diacono, M., Ferrante, V., Migliorini, P., Riva, F., Trinchera, A., Zanoli, R., Colombo, L. 2020. Levers and obstacles of effective research and innovation for organic food and farming in Italy. Agronomy, Vol. 10(8). https://doi.org/10.3390/agronomy10081181

4. Carayannis, E. G. and Campbell, D. F. J. 2009. 'Mode 3' and 'Quadruple Helix': Toward a 21st century fractal innovation ecosystem. International Journal of Technology Management (IJTM), Vol. 46(3), pp. 201-234. https://doi.org/10.1504/IJTM.2009.023374 
5. Carayannis, E. G. and Campbell, D. F. 2014. Developed democracies versus emerging autocracies: arts, democracy, and innovation in Quadruple Helix innovation system. Journal of Innovation and Entrepreneurship, Vol. 3(1), pp. 1-23. https://doi.org/10.1186/s13731-014-0012-2

6. Cavallini, S., Soldi, R., Friedl, J., and Volpe, M. 2016. Using the Quadruple Helix Approach to Accelerate the Transfer of Research and Innovation Results to Regional Growth. https://cor.europa.eu/en/engage/studies/Documents/quadruple-helix.pdf

7. Cronin, E., Fosselle, S., Rogge, E., Home, R. 2021. An analytical framework to study multi-actor partnerships engaged in interactive innovation processes in the agriculture, forestry, and rural development sector. Sustainability, Vol. 13(11). https://doi.org/10.3390/su13116428

8. CSP. 2021. RIG060. Pilsētu un lauku iedzīvotāju skaits reǵionos, pilsētās, novados un pagastos (Urban and rural population in regions, cities, municipalities and parishes). https://data.stat.gov.lv/pxweb/lv/OSP PUB/START POP IR IRS/RIG060

9. CSP. 2019. MIS020. Mājsaimniecību rīcībā esošo ienākumu sastāvs un struktūra pilsētās un laukos vidēji uz vienu mājsaimniecības locekli mēnesī (Composition and structure of household income in cities and rural areas on average per household member per month). https://data.stat.gov.lv/pxweb/lv/OSP_PUB/START_POP_MI_MIS/MIS020

10. Dwivedi, Y. K., Hughes, D. L., Coombs, C., Constantiou, I., Duan, Y., Edwards, J. S., Gupta, B., Lal, B., Misra, S., Prashant, P., Raman, R., Rana, N. P., Sharma, S. K., Upadhyay, N. 2020. Impact of COVID-19 pandemic on information management research and practice: Transforming education, work and life. International Journal of Information Management. https://doi.org/10.1016/j.ijinfomgt.2020.102211

11. Grando, S., Bonjean, I., Bartolini, F., Brunori, G., Vergamini, D., Prosperi, P., Mathijs, E. 2019. Deliverable D1.2 Refined conceptual framework. SUFISA. https://www.sufisa.eu/wp-content/uploads/2019/04/D1.2-Refined-conceptual-framework.pdf

12. Klerkx L., van Mierlo B., Leeuwis C. 2012. Evolution of systems approaches to agricultural innovation: concepts, analysis and interventions. In: Darnhofer I., Gibbon D., Dedieu B. (eds) Farming Systems Research into the 21st Century: The New Dynamic. Springer, Dordrecht. https://doi.org/10.1007/978-94-007-4503-2 20

13. Kolehmainen, J., Irvine, J., Stewart, L., Karacsonyi, Z., Szabó, T., Alarinta, J., Norberg, A. 2016. Quadruple Helix, innovation and the knowledge-based development: Lessons from remote, rural and less-favoured regions. Journal of the Knowledge Economy, Vol. 7(1), pp. 23-42. https://doi.org/10.1007/s13132-015-0289-9

14. Koopmans, M. E., Rogge, E., Mettepenningen, E., Knickel, K., Šūmane, S. 2018. The role of multi-actor governance in aligning farm modernization and sustainable rural development. Journal of Rural Studies, Vol. 59, pp. 252-262. https://doi.org/10.1016/j.jrurstud.2017.03.012

15. Latvia National Development Plan 2021-2027. https://www.pkc.gov.lv/sites/default/files/inline-files/NAP2027_apstiprin\%C4\%81 ts\%20Saeim\%C4\%81_1.pdf.

16. Makkonen, T., Kahila, P. 2021. Vitality policy as a tool for rural development in peripheral Finland. Growth and Change, Vol. 52(2), pp. 706-726. https://doi.org/10.1111/grow.12364

17. Malatzky, C., Gillespie, J., Couch, D. L., Cosgrave, C. 2020. Why place matters: A rurally-orientated analysis of COVID-19's differential impacts. Social Sciences \& Humanities Open, Vol. 2(1). https://doi.org/10.1016/j.ssaho.2020.100063

18. Nordberg, K., Mariussen, Å., Virkkala, S. 2020. Community-driven social innovation and quadruple helix coordination in rural development. Case study on LEADER group Aktion Österbotten. Journal of Rural Studies, Vol. 79, pp. 157-168. https://doi.org/10.1016/j.jrurstud.2020.08.001

19. van Oost, I. 2017. The European Innovation Partnership (EIP) Agricultural productivity and sustainability: Speeding up innovation. Proceedings of the "Added Value of Cooperation in Bioeconomy Research" In International Bioeast Conference. https://www.biosfere.be/wp-content/uploads/2017/12/Transmango-conference-Leuven-Inge-Van-Oost.pdf

20. Owen, R., Macnaghten, P, Stilgoe, J. 2012. Responsible research and innovation: From science in society to science for society, with society. Science and Public Policy, Vol. 39(6), pp. 751-760. https://doi.org/10.1093/scipol/scs093

21. Pigford, A. E., Hickey, G. M., Klerkx, L. 2018. Beyond agricultural innovation systems? Exploring an agricultural innovation ecosystems approach for niche design and development in sustainability transitions. Agricultural Systems, Vol. 164, pp. 116-121. https://doi.org/10.1016/j.agsy.2018.04.007

22. Rowan, N. J., Galanakis, C. H. 2020. Unlocking challenges and opportunities presented by COVID-19 pandemic for cross-cutting disruption in agri-food and green deal innovations: Quo Vadis? Science of The Total Environment, Vol. 748. https://doi.org/10.1016/j.scitotenv.2020.141362

23. UN-Habitat. 2020. Mainstreaming Urban-Rural Linkages in National Urban Policies: National Urban Policy Guide. https://unhabitat.org/sites/default/files/2020/06/mainstreaming-url-in-nup-guide-_web.pdf 